\title{
GLACIAL AND PERIGLACIAL TRANSFORMATION OF PALAEOKARST IN THE LUBLIN-VOLHYNIA REGION (SE POLAND, NW UKRAINE) ON THE BASE OF TL DATING
}

\author{
RADOSLAW DOBROWOLSKI ${ }^{1}$ and STANISLAW FEDOROWICZ ${ }^{2}$ \\ ${ }^{1}$ Institute of Earth Sciences, Maria Curie-Sklodowska University, \\ Krasnicka 2 cd, 20-718 Lublin, Poland \\ ${ }^{2}$ Department of Geomorphology and Quaternary Geology, Gdansk University, \\ Dmowskiego 16a, 80-952 Gdańsk, Poland
}

Received 30 January 2007

Accepted 8 March 2007

\begin{abstract}
Distinctly diverse results of TL dating are obtained for the deposits with similar lithofacial features but filling morphologically differentiated karst palaeoforms (dolines, pipes, pockets). The infillings of dolines and pipes are mostly of the Saalian age. Based on sedimentological analysis, their formation conditions are related to sub- or/and terminoglacial environment. The age obtained for all infillings of pockets is underestimated in comparison with lithostratigraphic data. A close genetic relationship between these forms and periglacial conditions seems to indicate that the reduction of TL signal is mostly influenced by the disintegration of grains resulted from the repeated freezing and thawing of glaciogenic deposits. A considerable influence of frost weathering on the decrease of thermoluminescence intensity of mineral grains is indirectly confirmed by the results of experimental investigations consisting in the repeated TL measurements of pockets' infillings after successive freeze-thaw cycles.
\end{abstract}

Keywords: Thermoluminescence dating, palaeokarst, glacial transformation, periglacial transformation, Lublin-Volhynia karst region, Poland SE, Ukraine NW

\section{INTRODUCTION}

Thermoluminescence dating methods have been used in the Quaternary geology for more than fifty years. The results of TL dating, considered as an indicator of deposit age, are used for construction of local or regional stratigraphic schemes (among others Boguckyj and Łanczont, 2002; Dolecki, 1995; Frechen,1999; Frechen et al., 2003; Harasimiuk et al., 1988; Kukla, 1975; Lindner et al., 1985, 1991; Maruszczak, 1986). Considerably more rarely they are used in litho- and morphogenetic discussions, and interpreted not as the age of deposit but of a process, which transformed this deposit (Dzierżek and Stańczuk, 2006; Raukas and Stankowski, 2005; Stankowski, 2001a, b). However, such approach requires evidence for postdepositional zeroing of the TL signal to residual level as a result of mechanical (friction effect), thermal, and/or insolar influences on mineral grains

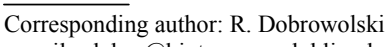

e-mail: rdobro@biotop.umcs.lublin.pl

ISSN 1897-1695 (online) (c) 2007 GADAM Centre,

Institute of Physics, Silesian University of Technology.

All rights reserved.
(Fedorowicz, 2006). Moreover, the TL ages divergent from stratigraphic schemes (i.e. incompatible with expectations) are rarely examined in terms of postdepositional transformation of deposits. They are most often omitted in palaeogeographic interpretations or treated as "measurement errors". In extreme cases, the divergences of the TL results with the "expected" age of the deposit (its lithostratigraphic situation determined on the basis of mineral-petrographic, sedimentologic and other features) can raise doubts about the reliability of thermoluminescence dating in general.

The authors of this paper encountered such a research problem when they tried to interpret the TL ages obtained for the series of samples taken from the infillings of palaeokarst forms occurring in the Lublin-Volhynia karst region (SE Poland, NW Ukraine). These forms and deposits are well examined in respect of geology and micromorphology (Dobrowolski, 2006). The obtained results of TL dating for morphometrically different forms (dolines, pipes, pockets) were distinctly differentiated in spite of similar lithofacial features of the infillings. All 
infillings of pockets gave the ages which are underestimated in comparison with lithostratigraphic data. Direct genetic relationship between these forms and periglacial conditions suggests that the reduction of TL signal was mostly caused by the disintegration of grains resulting from repeated freezing and thawing of glaciogenic deposits.

\section{SETTING OF THE LUBLIN-VOLHYNIA KARST REGION}

The Lublin-Volhynia karst region (Fig. 1) encompasses the Lublin-Volhynia uplands with the Polesie situated in their foreland, and is the largest area of the continuous occurrence of unique chalk karst in Europe (vide Rodet, 1991). Its morphological and hydrogeological identity is conditioned by lithological features of carbonate rocks developed as chalk or marl facies. Little resistance of these rocks to destruction results in the absence of underground water drainage typical of classic karst; relief differences are also important (Dobrowolski, 1998; Harasimiuk, 1975; Lomaev, 1979; Maruszczak, 1966).

The state of preservation of palaeokarst forms and deposits representing successive cycles of development is different. However, it is possible to distinguish several main stages of activity of karst processes (from Palaeogene to Holocene) related to the changes of climatic conditions and/or phases of tectonic activity of the area (Dobrowolski, 2006). The Neopleistocene dolines, pipes, and pockets with glaciogenic infillings of the Saalian age are the most frequently found and best-examined palaeokarst forms. In many cases, they have features of post- or syngenetic transformation (Dobrowolski, 2004, 2006).

The Neopleistocene palaeokarst forms are mostly filled with the following deposits: (1) massive diamictic sands representing mass flows in sub- and/or terminoglacial environment or (2) horizontally laminated, sandysilty rhythmite settled from suspension in ephemeral paraglaciolimnic water bodies. The occurrence of bottom massive clays, identified as residuum of weathered carbonate rocks, is a typical feature of all palaeokarst infillings. Deformation structures (involutions) occurring in the deposits filling the majority of shallow pockets prove cryogenic transformation of primary glaciogenic infillings (Dobrowolski, 2006).

\section{TL DATING OF PALAEOKARST INFILLINGS}

\section{Methodology}

TL dating was completed in Gdańsk University. The dose rate $\left(D_{r}\right)$ was measured with the MAZAR 95 scintillation spectrometer. Dry deposit was placed in plastic Marinelli containers with a volume of $1.5 \mathrm{dm}^{3}$ and placed in the protective chamber of the spectrometer. 20 measurements were made, each of which lasted $2000 \mathrm{~s}$. The sum of impulses in channels determined the concentration of the three nuclides: ${ }^{226} \mathrm{Ra},{ }^{232} \mathrm{Th}$ and ${ }^{40} \mathrm{~K}$. The values obtained were converted into dose rates for alpha, beta and gamma radiation. Corrections were made to account for earlier measurements of deposit humidity (Aitken and Xie, 1985. The cosmic radiation dose $\left(d_{c}\right)$ was added to

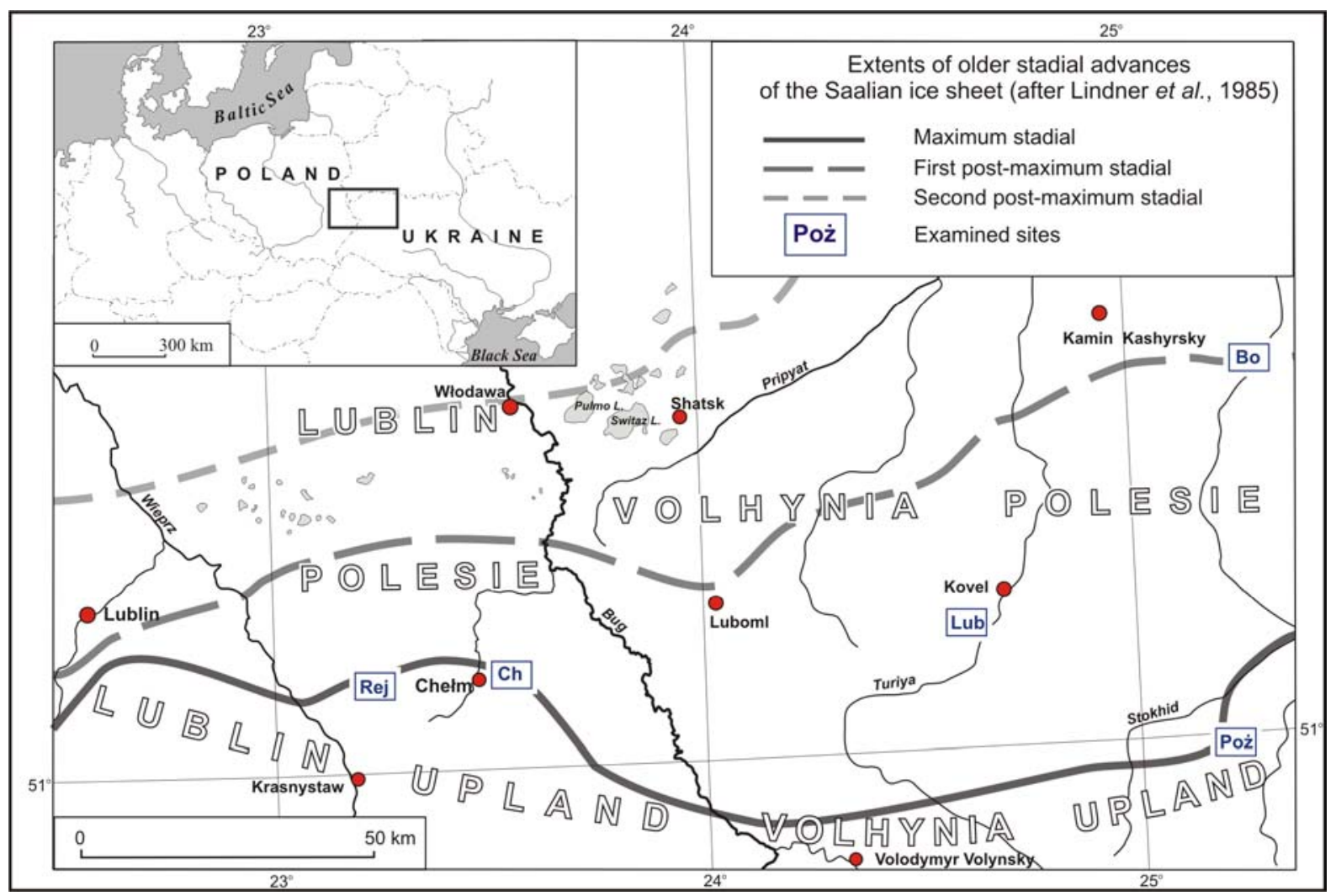

Fig. 1. Location sketch of the studied area with the distribution of the examined sites: Rej-Rejowiec, Ch - Chełm, Lub - Lubliniec, Bo-Borki, Poż - Pożarki. 
the estimated alpha, beta and gamma radiation doses. The uncertainty of the dose rate estimation is about $3 \%$. For the estimation of the equivalent dose from the total mass of the sample, a fraction of grains with a size of $80-100 \mu \mathrm{m}$ was separated. The grains, isolated with the sieve method, were subjected to initial extraction to remove the external layer from the quartz grains and to clean their surface. The grains are then treated with $10 \%$ $\mathrm{HCl}$ acid and $40 \% \mathrm{HF}$ acid within 24 hours. The samples were rinsed with distilled water and dried at room temperature. The absorbed dose ED was measured with the multi aliquot regeneration method (Fedorowicz, 2006). For each aliquot of extracted grains from 10 to 20 diagrams of the glow curve were prepared, as well as a plateau check test. Its results shed light on the accuracy of the initial TL value estimation and give some hints whether the laboratory time of sample bleaching was optimal (Bluszcz, 2000). The sensitivity of grains is also checked by way of complementary measurements according to the technique used in additive method. The uncertainty of ED determination is about $10 \%$. Glow curves are done with the use of a reader-analyser type RA'94. The samples are heated up to $400^{\circ} \mathrm{C}$ with the heating speed of $8^{\circ} \mathrm{C}$ per second.

\section{Results}

In total, $25 \mathrm{TL}$ ages were obtained using regeneration method for the typologically differentiated Neopleistocene palaeokarst forms (dolines, pipes and pockets) occurring at five sites (Fig. 1). In several cases, the equivalent dose for the same samples was determined by additive method, which gives additional opportunity to estimate a potential change of grain sensitivity (saturation effect - Table 1).

The obtained results indicate the occurrence of distinct regularities related to different genetic types of palaeokarst forms, and allow us to formulate the following generalizations:

1) Glaciogenic deposits (sandy-silty rhythmite or diamictic sands) filling relatively deep pipes and dolines $(>2 \mathrm{~m})$ are of the Saalian age $(\approx 250-300 \mathrm{ka} \mathrm{BP})$.

2) The TL ages of the infillings of shallow pockets $(<1 \mathrm{~m})$ are very young and indicate that the infillings were deposited during the Pleniglacial.

Table 1. Results of thermoluminescence dating ( $R$ - regeneration method; $A$ - additive method) of the materials filling the karst palaeoforms in the sites from Lublin-Volhynia karst region, after Dobrowolski (2006)

\begin{tabular}{|c|c|c|c|c|c|c|c|c|c|}
\hline Sample & $\begin{array}{c}\text { Depth } \\
\text { (m) }\end{array}$ & $\begin{array}{l}\text { Lab.No } \\
\text { UG - }\end{array}$ & $\begin{array}{c}d_{\alpha} \\
\text { (Gy/ka) }\end{array}$ & $\begin{array}{c}d_{\beta} \\
\text { (Gylka) }\end{array}$ & $\begin{array}{c}d_{y} \\
\text { (Gy/ka) }\end{array}$ & $\begin{array}{c}d_{c} \\
(G y / k a)\end{array}$ & $\begin{array}{c}D_{r} \\
\text { (Gy/ka) }\end{array}$ & $\begin{array}{l}\text { ED } \\
\text { (Gy) }\end{array}$ & $\begin{array}{l}\text { TL Age } \\
\text { (ka BP) } \\
\end{array}$ \\
\hline \multicolumn{10}{|l|}{ POCKETS } \\
\hline Ch-11/1 & 0.60 & 5650 & 0.03 & 0.50 & 0.22 & 0.14 & $0.89 \pm 0.03$ & $\begin{array}{ll}\text { R } & 164.9 \pm 15.4\end{array}$ & $185.3 \pm 21.4$ \\
\hline Ch-11/2 & 0.30 & 5651 & 0.03 & 0.62 & 0.40 & 0.15 & $1.19 \pm 0.03$ & $\begin{array}{ll}\mathbf{R} & 83.5 \pm 7.9 \\
\end{array}$ & $70.0 \pm 9.8$ \\
\hline Ch-11/3 & 0.20 & 5652 & 0.03 & 0.71 & 0.44 & 0.15 & $1.33 \pm 0.04$ & $\begin{array}{ll}\mathbf{R} & 94.3 \pm 9.8 \\
\end{array}$ & $70.9 \pm 9.6$ \\
\hline Ch-35/1 & 0.90 & 5657 & 0.01 & 0.44 & 0.16 & 0.14 & $0.75 \pm 0.03$ & $\begin{array}{ll}\text { R } & 59.4 \pm 6.9\end{array}$ & $79.2 \pm 10.2$ \\
\hline Ch-35/2 & 0.70 & 5658 & 0.02 & 0.39 & 0.20 & 0.14 & $0.75 \pm 0.03$ & $\begin{array}{ll}\mathbf{R} & 64.9 \pm 8.6 \\
\end{array}$ & $86.5 \pm 11.6$ \\
\hline Poż- 2/1 & 0.50 & 5845 & 0.01 & 0.64 & 0.73 & 0.14 & $1.52 \pm 0.05$ & $\begin{array}{lr}\mathbf{A} & 59.0 \pm 6.6 \\
\mathbf{R} & 56.4 \pm 6.4 \\
\end{array}$ & $\begin{array}{l}38.1 \pm 4.4 \\
37.1 \pm 4.0 \\
\end{array}$ \\
\hline \multicolumn{10}{|l|}{ PIPES } \\
\hline$\overline{\mathrm{Ch}-1 / 1}$ & 2.00 & 5750 & 2.06 & 2.65 & 1.56 & 0.12 & $6.61 \pm 0.2$ & $\mathbf{R}>650$ & $>101.7$ \\
\hline $\mathrm{Ch}-1 / 2$ & 1.80 & 5751 & 0.99 & 1.96 & 0.98 & 0.12 & $4.04 \pm 0.2$ & R $1020 \pm 120$ & $252.1 \pm 39$ \\
\hline Ch-1/3 & 1.20 & 5752 & 0.57 & 1.13 & 0.52 & 0.13 & $2.35 \pm 0.1$ & R $\quad 660 \pm 70$ & $280.7 \pm 42$ \\
\hline Ch-1/4 & 0.50 & 5753 & 0.26 & 0.59 & 0.28 & 0.14 & $1.27 \pm 0.1$ & R $314.0 \pm 32$ & $247.0 \pm 37$ \\
\hline$\overline{C h}-2 / 1$ & 2.00 & 5763 & 0.00 & 0.28 & 0.14 & 0.13 & $0.55 \pm 0.03$ & $\begin{array}{ll}\mathbf{A} & 129.0 \pm 13 \\
\mathbf{R} & 108.8 \pm 11 \\
\end{array}$ & $\begin{array}{l}234.5 \pm 25 \\
192.8 \pm 20 \\
\end{array}$ \\
\hline$\overline{\mathrm{Ch}-9 / 1}$ & 1.20 & 5762 & 0.01 & 0.53 & 0.36 & 0.14 & $1.04 \pm 0.04$ & $\begin{array}{lr}\text { A } & 333.8 \pm 32 \\
\text { R } & 279.8 \pm 28 \\
\end{array}$ & $\begin{array}{l}321.0 \pm 33 \\
263.3 \pm 29 \\
\end{array}$ \\
\hline Lub-1/1 & 2.00 & 5659 & 0.01 & 0.25 & 0.10 & 0.14 & $0.50 \pm 0.03$ & R $178.0 \pm 17$ & $356.0 \pm 47$ \\
\hline Lub-1/2 & 1.00 & 5843 & 0.01 & 0.42 & 0.63 & 0.13 & $1.19 \pm 0.03$ & $\begin{array}{ll}\text { A } & 528.7 \pm 52 \\
\text { R } & 315.3 \pm 32\end{array}$ & $\begin{array}{l}444.2 \pm 66 \\
264.9 \pm 37\end{array}$ \\
\hline Bor-1/1 & 2.00 & 5870 & 0.08 & 1.39 & 0.86 & 0.10 & $2.51 \pm 0.08$ & R $748.8 \pm 62$ & $298.3 \pm 26$ \\
\hline Rej-1/1 & 1.20 & 4201 & 1.45 & 2.37 & 1.31 & 0.13 & $5.26 \pm 0.07$ & $\mathbf{R}>650$ & $>123.5$ \\
\hline Rej-1/2 & 0.90 & 4202 & 0.40 & 1.11 & 0.47 & 0.14 & $2.11 \pm 0.06$ & R $\quad 650+68$ & $306.7+46$ \\
\hline Rej-1/3 & 0.20 & 4203 & 1.73 & 1.61 & 1.31 & 0.15 & $4.79 \pm 0.08$ & $\mathbf{R}>650$ & $>135.5$ \\
\hline \multicolumn{10}{|l|}{ DOLINES } \\
\hline$\overline{\text { Ch-24/1 }}$ & 1.00 & 5768 & 0.01 & 0.68 & 0.36 & 0.14 & $1.19 \pm 0.04$ & $\begin{array}{l}A>120.0 \\
R \quad 305.2 \pm 30\end{array}$ & $\begin{array}{l}>100.8 \\
256.5 \pm 27\end{array}$ \\
\hline$\overline{\mathrm{Ch}-24 / 2}$ & 2.00 & 5769 & 0.01 & 1.05 & 0.67 & 0.13 & $1.86 \pm 0.06$ & $\begin{array}{ll}\text { A } & 488.4 \pm 49 \\
\text { R } & 508.3 \pm 51 \\
\end{array}$ & $\begin{array}{l}262.6 \pm 28 \\
273.3 \pm 29 \\
\end{array}$ \\
\hline
\end{tabular}

$d_{a}, d_{\beta}, d_{\gamma}, d_{c}-a, \beta, \gamma$, cosmic dose rate, $D_{r}-$ dose rate, ED - Equivalent Dose 


\section{DISCUSSION}

\section{TL ages of infillings of the dolines and pipes vs. sedi- mentological analysis}

The defined age of dated samples, indicating the Saalian age of deposits, is consistent with lithostratigraphic interpretation (Dobrowolski, 2006; Dobrowolski et al., 1995; Harasimiuk, 1975; Harasimiuk et. al., 1981; Rzechowski, 1962). The exceptions to the principle, found in several cases, require a comment giving the basis for morphogenetic interpretation. The following facts draw attention:

1) The undefined age of the bottom massive clays (Ch1/1, Rej-1/1). Taking into account weathering origin of the clay (= karst crust), the undefined age seems to be the only acceptable result from the methodic point of view because the aggradation of this material occurred without contact with sunlight. Exposure to sunlight is necessary for the reduction of energy contained in grains, which is measured during luminescence measurements.

2) Divergence of the ages obtained for the sample Lub$1 / 2$ by different methods (the ED value obtained by additive method is almost two times higher).

3) Very low dose rate $\left(D_{r}\right)$ of the sample Lub-1/1. Determination of the equivalent dose accumulated by this sample, reaching $900 \mathrm{~Gy}$, indicates that the growth curve is linear.

The most probable explanation of the problems mentioned in point (2) and (3) is the occurrence of mixed-age (Tertiary and Quaternary) grains in the samples. Such an interpretation seems to be indirectly confirmed by the high content of local Palaeogene and Neogene material commonly found in glaciogenic deposits of this area (among others Harasimiuk et al., in press; Lomaev, 1979; Mojski, 1968; Rühle, 1933). Moreover, the admixture of older (Palaeogene?) grains in the sample from a depth of $2.0 \mathrm{~m}(\mathrm{Lub}-1 / 1)$ is probably greater than in the sample from a depth of $1.0 \mathrm{~m}$ (Lub-1/2). Great divergence between the TL ages obtained using additive and regeneration methods (sample Lub-1/2) indicates that sensitivity of the examined grains changed.

The interpretation of TL ages of the deposits filling the Neopleistocene pipes and dolines presented above is consistent with palaeogeographic reconstruction based on sedimentologic and micromorphologic data (Dobrowolski, 2006). Both types of palaeoforms bear traces of intensive glacial transformation (ibid.). Pipes were probably originally formed as evorsion hollows in chalk surface in subglacial environment. With the decreasing energy of meltwater flows the following phenomena could have occurred: (i) rapid disappearance of water flow, and appearance of mass flows of flow till type (= infillings composed of massive diamictic sand), or (ii) development of small water bodies of paraglaciolimnic accumulation in the dispersed drainage zones (= infillings composed of horizontally laminated sands and silts). High energy of meltwater flow was also responsible for the removal of the primary (Neogene?) infilling of dolines, to the truncation of karst-related residual clay. Therefore, karstification process in pipes, which caused the development of bottom massive clays at the contact of infilling with car- bonate rock, was secondary relative to the process responsible for the development of these forms, and relatively younger from their infillings (ibid.).

\section{TL ages of infillings of the pockets vs. sedimentologi- cal analysis}

Uncritical interpretation of the obtained dating results suggesting the Plenivistulian age of the infillings of pockets is contrary to the current geologic knowledge. These deposits are related to the maximum stadial of the Saalian Glacial (Lindner, et al. 1985, 1991; Harasimiuk, et al., in press). In respect of lithofacies they are the same diamictic sands of mass flows as the infillings of pipes and some dolines. However, they bear distinct traces of periglacial transformation (Dobrowolski et al., 1995; Harasimiuk et al., in press) as evidenced by the occurrence of cryogenic structures (involutions). Moreover, micromorphologic image of these deposits shows disintegration of quartz grains without distinct traces of displacement. Grain material disintegrated in such a way is described by van Vliet-Lanoë (1985) as "crushed grains" and unambiguously related to the intensive process of frost weathering in periglacial environment. Periglacial conditions are also evidenced by the incorporation of grain material in ductile chalk, which is commonly found in the deposits deformed cryogenically in permafrost active layer (Dobrowolski, 2006; Jahn, 1951; Maruszczak, 1968; van Vliet-Lanoë, 1988).

Therefore, the obtained TL ages of the pockets' infillings should be related not to the process of their deposition but to postdepositional destruction. In order to determine the influence of frost weathering on the reduction of TL signal, we decided to perform an experiment. The samples of the pockets' infillings were subjected to cyclic freezing and thawing, and their thermoluminescence was measured.

\section{Experimental investigations}

The influence of freezing on the thermoluminescence of mineral grains in glaciogenic deposits (mostly tills) was the subject of experimental investigations carried out by Bluszcz (1989), Fedorowicz (1994), PrószyńskaBordas et al. (1988). These experiments revealed the reduction of thermoluminescence after successive freezethaw cycles but without distinct regularities (ibid.).

The authors performed similar experiments for glaciogenic deposits filling the $\mathrm{Ch}-35$ pocket from the Chełm site. Four samples, each of $200 \mathrm{~g}$ in weight, were taken at $25 \mathrm{~cm}$ intervals (Fig. 2). Initial deposit moisture was measured. Each sample was homogenized by stirring into water, and divided into five equal sub-samples. Four of them were subjected to freeze-thaw cycles. Each cycle consisted of one freezing (twenty-four hours at a temperature of $-12^{\circ} \mathrm{C}$ ) and one thawing (twenty-four hours at a temperature of about $+20^{\circ} \mathrm{C}$ ). Thermoluminescence of each sample was measured five times, i.e. of the untreated sub-sample, and of the four sub-samples after successive five freeze-thaw cycles (Table 2).

The results of experiment are as follows:

- The TL intensity of samples increases with depth (except for the lowest Ch-35/4 sample); 


\begin{tabular}{cccccc}
\hline $\begin{array}{c}\text { Sample } \\
\text { (initial moisture }\end{array}$ & \multicolumn{5}{c}{ TL intensity after each five successive freeze-thaw cycles } \\
\cline { 2 - 6 } in \%) & $\mathbf{0}$ & $\mathbf{5}$ & 10 & 15 & $\mathbf{2 0}$ \\
\hline Ch-35/1 (2.2\%) & $650 \pm 48$ & $674 \pm 53$ & $627 \pm 42$ & $582 \pm 54$ & $533 \pm 46$ \\
Ch-35/2 (3.1\%) & $783 \pm 64$ & $769 \pm 70$ & $742 \pm 61$ & $720 \pm 58$ & $688 \pm 63$ \\
Ch-35/3 (5.6\%) & $846 \pm 75$ & $876 \pm 82$ & $893 \pm 86$ & $826 \pm 68$ & $801 \pm 62$ \\
Ch-35/4 (7.9\%) & $654 \pm 56$ & $682 \pm 63$ & $642 \pm 38$ & $596 \pm 57$ & $573 \pm 43$ \\
\hline
\end{tabular}

Table 2. Changes of the TL intensity after successive freeze-thaw cycles.
- The relationship between the TL intensity and the number of freeze-thaw cycles is very similar in most samples. In three cases the TL intensity increased first, and then consistently decreased. Only in the Ch-35/2 sample the TL intensity consistently decreased after each five freeze-thaw cycles;

- Twenty freeze-thaw cycles in all samples resulted in the decrease of the TL intensity from 12 to $18 \%$ in comparison to fresh deposits. The TL intensity after 20 cycles was even more than $20 \%$ lower in comparison with that after 5 cycles. This is evidence for a considerable influence of freezing on the TL intensity, while the shape of TL glow curves remains unchanged;

- The progressive decrease of the TL signal in the successive measurements of equivalent dose indicates that the examined deposits were probably considerably "rejuvenated" as a result of cyclic freezing and thawing.

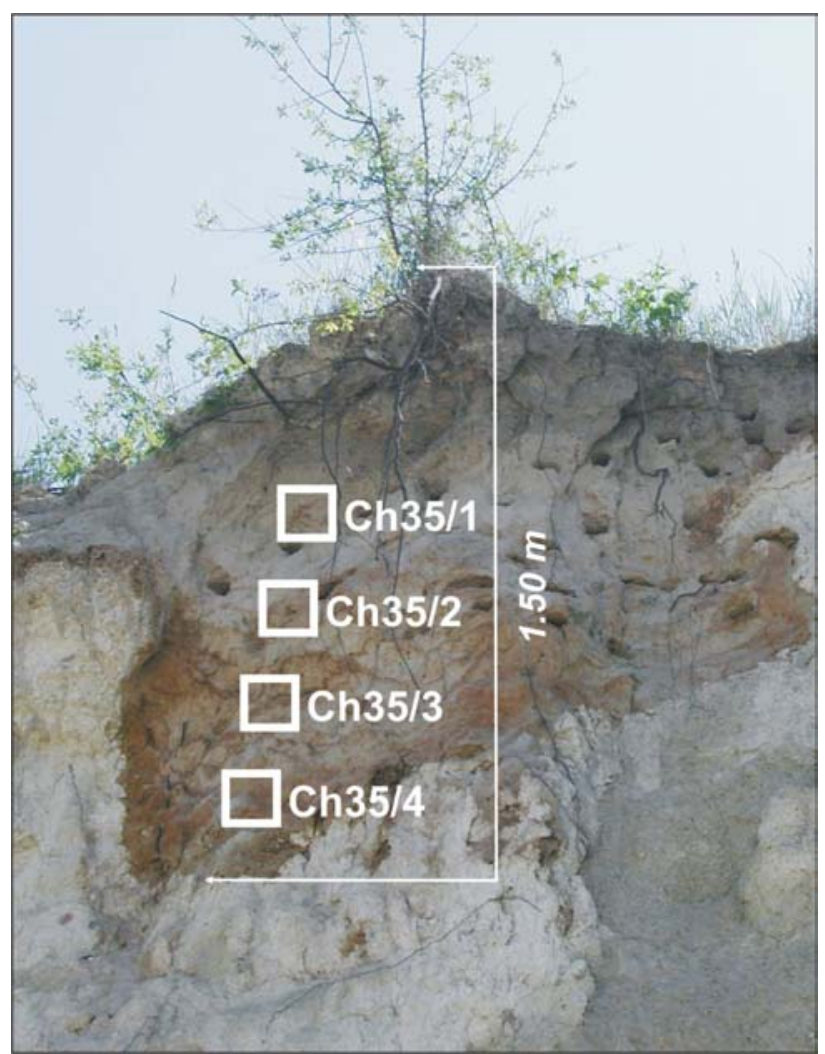

Fig. 2. Chełm site - pocket Ch-35 - distribution of sampling sites for TL dating.

\section{CONCLUSIONS}

Despite apparent inconsistency of the obtained results, we tried to interpret them basing on the current geological knowledge in the context of sedimentology, lithostratigraphy and palaeogeography. Taking into account the complexity of litho- and morphogenetic processes in glacial and periglacial environments, we are of the opinion that a "different from the norm" result of TL dating should be treated as the age of a process deforming a deposit and not the age of a deposit as such. Such approach to the results allows us to make more thorough palaeoenvironmental interpretation.

The gathered data evidence the complexity of morphogenetic processes occurring during freeze-thaw cycles in the top parts of carbonate rocks covered by unconsolidated deposits. Further studies are necessary to verify the results obtained till now.

\section{ACKNOWLEGMENTS}

The research was partly supported by Ministry of Science and Higher Education: grant no. 2PO4E 02427.

\section{REFERENCES}

Aitken MJ and Xie J, 1985. Moisture correction for annual gamma dose, Ancient TL 8: 6-9.

Bluszcz A, 1989. Wpływ przemrażania na termoluminescencję ziaren minerałów w glinach (The influence of freezing on the thermoluminescence of mineral grains in clay). Zeszyty Naukowe Politechniki Śląskiej, Seria Matematyka - Fizyka 61, Geochronometria 6: $213-218$ (in Polish).

Bluszcz A, 2000. Datowanie luminescencyjne osadów czwartorzędowych - teoria, ograniczenia, problemy interpretacyjne (Luminescencje dating of Quaternary sediments - theory, limitations, interpretation problems). Geochronometria 17: 1-104 (in Polish).

Boguckyj A and Łanczont M, 2002. Stratygrafia lessów Naddniestrza Halickiego (Loess stratigraphy in the Halyč Prydnistrov'ja region). Studia Geologica Polonica 119: 315-327 (in Polish).

Dobrowolski R, 1998. Strukturalne uwarunkowania rozwoju współczesnej rzeźby krasowej na międzyrzeczu środkowego Wieprza i Bugu (Structural conditions of recent karst relief development in the middle Wieprz and Bug interfluve). UMCS Press, Lublin: 88 pp (in Polish).

Dobrowolski R, 2004. Some aspects of paleokarst development in the Upper Cretaceous rocks of Chełm Hills (Lublin Upland, Eastern Poland). Geomorphologia Slovaca 1 (IV): 22-27.

Dobrowolski R, 2006. Glacjalna i peryglacjalna transformacja rzeźby krasowej północnego przedpola wyżyn lubelsko-wołyńskich, Polska SE, Ukraina NW (Glacial and periglacial transformation of karst relief in the northern foreland of the Lublin-Volhynia uplands, SE Poland, NW Ukraine). UMCS Press, Lublin: 188 pp (in Polish).

Dobrowolski R, Fedorowicz S and Kusiak J, 1995. Wiek i geneza krasu kopalnego w kamieniołomie kredy piszacej w Chełmie (Age and origin of palaeokarst in chalk quarry in Chełm). Conference Proceedings "Problems of Quaternary geomorphology and palaeogeography", Lublin 10-11.04.1995: 76-78 (in Polish). 
Dolecki L, 1995. Litologia i stratygrafia mezoplejstoceńskich utworów lessowych południowo-wschodniej części Wyżyny Lubelskiej (Lithology and stratigraphy of the Mesopleistocene loesses and loess-like sediments in South-East part of the Lublin Upland). UMCS Press, Lublin: 169 pp. (in Polish).

Dzierżek J and Stańczuk D, 2006. Record and palaeogeographical implications of Pleistocene periglacial processes in the Drohiczyn Plateau, Podlasie Lowland (Eastern Poland). Geological Quarterly 50 (2): 219-228.

Fedorowicz S, 1994. Wyniki badań własności termoluminescencyjnych glin zwałowych w laboratorium gdańskim (Laboratory investigations of thermoluminescence properties of tills). Geochronometria 10: 253-262 (in Polish).

Fedorowicz S, 2006. Metodyczne aspekty luminescencyjnego oznaczania wieku osadów neoplejstoceńskich Europy Środkowej (Methodological aspects of luminescence dating of Central Europe's Neopleistocene deposits). Gdańsk University Press: 156 pp. (in Polish).

Frechen M, 1999. Upper Pleistocene less stratigraphy in Southern Germany. Quaternary Geochronology 18: 243-269.

Frechen M, Oches EA and Kohfeld KE, 2003. Loess in Europe - mass accumulation rates during the Last Glacial Period. Quaternary Science Reviews 22: 1835-1857.

Harasimiuk M, 1975. Rozwój rzeźby Pagórów Chełmskich w trzeciorzędzie i czwartorzędzie (Relief evolution of the Chełm Hills in the Tertiary and Quaternary). Prace Geograficzne IG PAN 115: 1-94 (in Polish).

Harasimiuk M, Jezierski W, Król T and Szwajgier W, 1981. Tertiary and Quaternary fossil karst in the Cretaceous rocks of chalk type in eastern Poland. Proceedings European Regional Conference of Speleology, Sofia, Bulgaria, 22-28 Sept. 1980 v2: 45-50.

Harasimiuk M, Jezierski W and Rzechowski J, in press. Szczegółowa Mapa Geologiczna Polski, 1:50000, ark. Chetm (Detailed Geological Map of Poland, scale 1:50,000; Chełm Sheet), Geological Press, Warsaw.

Harasimiuk M, Maruszczak H and Wojtanowicz J, 1988. Quaternary stratigraphy in the Lublin region, Southeastern Poland. Quaternary Studies in Poland 8: 15-25.

Jahn A, 1951. Zjawiska krioturbacyjne współczesnej i plejstoceńskiej strefy peryglacjalnej (Cryoturbation phenomena of the present and Pleistocene periglacial zone). Acta Geologica Polonica 2 (1-2): 159-290 (in Polish).

Kukla GJ, 1975. Less stratigraphy of Central Europe. In: Butzer KW and Isaac GL, eds, After the Australopithecines, Mouton, The Hague, Köln: 277-309.

Lindner L, Maruszczak H and Wojtanowicz J, 1985. Zasięgi i chronologia starszych zasunięć stadialnych lądolodu środkowopolskiego (Saalian) między górną Wartą i Bugiem (Extents and chronology of early stadial advances of the Mid-Polish (Saalian) ice sheet between the Upper Warta and Bug Rivers). Przeglad Geologiczny 2: 57-63 (in Polish).

Lindner L, Maruszczak H, Palienko VP and Wojtanowicz J, 1991. Extents and chronology of stadial advances of the Saalian I ice sheet between the Odra and Dnieper Rivers. Annales UMCS, sec. B, 46: 139-153.

Lomaev AA, 1979. Geologija karsta Volyno-Podolii (Karst geology of Volhynia-Podolia). Naukova Dumka, Kiev: 132 pp (in Ukrainian).

Maruszczak H, 1966. Zjawiska krasowe w skałach górnokredowych międzyrzecza Wisły i Bugu - typ krasu kredy piszącej (Karst phenomena in the Upper Cretaceous rocks of the Vistula and Bug interfluve - chalk karst type). Przeglad Geograficzny 38 (3): 339 370 (in Polish).

Maruszczak H, 1968. Przebieg zjawisk w strefie peryglacjalnej w okresie ostatniego zlodowacenia w Polsce (The course of phenomena in the periglacial zone during the last glaciation). Prace Geograficzne IG PAN 74: 157-200 (in Polish).

Maruszczak H, 1986. Loesses in Poland, their stratigraphy and paleogeographical interpretation. Annales UMCS, sec. B, 41: 15-54.

Mojski JE, 1968. Objaśnienia do Szczegółowej Mapy Polski, 1:50 000, ark. Pawłów (Explanations to Detailed Geological Map of Poland, scale 1:50,000; Pawłów Sheet), Geological Press, Warsaw: 46 pp (in Polish).

Prószyńska-Bordas H, Stańska-Prószyńska W and Prószyński M, 1988. TL dating of bleached sediments by the regeneration method. Quaternary Science Reviews 7: 265-271.

Rauskas A and Stankowski W, 2005. Influence of sedimentological composition on OSL dating of glaciofluvial deposits: examples from Estonia. Geological Quarterly 49 (4): 463-470.

Rodet J, 1991. Les karsts de la craie - étude comparative. (Chalk karsts - comparative study) Thèse du Doctorat d'Etat. Université de Paris IV-Sorbonne: $562 \mathrm{pp}$ (in French).

Rühle E, 1933. Morfologja i geologja wzgórz w dorzeczu górnej Prypeci (Morphology and geology of hills in the upper Prypet catchment). Wiadomości Stużby Geograficznej 7: 362-390 (in Polish).

Rzechowski J, 1962. Kopalne formy krasowe z kamieniołomu w Rejowcu (Fossil karst forms from Rejowiec quarry). Geological Quarterly 6 (1): 109-123 (in Polish).

Stankowski W, 2001a. ${ }^{14} \mathrm{C}$ and TL dating as a method of establishing the origin of kettle-like hollows. Geochronometria 20: 103-106.

Stankowski W, 2001b. The geology and morphology of the natural reserve "Meteoryt Morasko". Planetary and Space Science 49: 749-756.

Van Vliet-Lanoë B, 1985. Frost effects in soils. In: J. Boardman, ed., Soil and Quaternary Landscape Evolution. Wiley, London: 115156.

Van Vliet-Lanoë B, 1988. The genesis of cryoturbations and their significance in environmental reconstruction. Journal of Quaternary Sciences 3: 85-96. 